\title{
The President's Proposed Corporate Tax Reforms: A Move Toward Tax Neutrality
}

\author{
Dallas S. Batten and Mack Ott
}

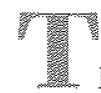

HE President has proposed a significant change in the federal income tax law, The President's Tax Proposals to the Congress for Fairness, Growth and Simplicity, (hereafter PTP). Included in PTP are proposed corporate business tax reforms that, in general, would lower the marginal tax rate on business income while broadening the corporate tax base. Because, on net, these proposals would increase the average tax rate on business income, they have been widely criticized as having deleterious effects on U.S. investment, employment and economic growth.

By focusing on the negative macroeconomic effects, however, these critics have overlooked some of the proposed tax reform's positive allocative effects. The President's proposal would make tax rates across industries and activities more uniform and reduce the distorting influences of inflation, thereby diminishing the role of the tax structure in the allocation of productive resources.

Dallas S. Batten, a research officer at the Federal Reserve Bank of St. Louis, is currently on leave as a senior staff economist at the Council of Economic Advisers. Views expressed are not necessarily those of the council. Mack Ott is a senior economist at the Federal Reserve Bank of St Louis. James C. Poletti provided research assistance.

See, for example, Rowen (1985), Sterngold (1985) and Yemma (1985).
The purpose of this article is to examine the allocative effects of the President's proposal. We begin by describing the concepts of economic efficiency and tax neutrality, two important criteria for evaluating the reform. Then, the basic points contained in the President's proposal are outlined and evaluated against these criteria.

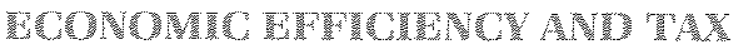

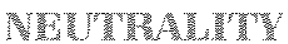

Fundamentally, economic efficiency means using resources in their highest valued activity. A simple example using the demand for and the supply of apples demonstrates the concept of efficiency and shows how competitive markets result in efficient resource use. ${ }^{2}$ The supply curve in figure 1 represents the minimum price that producers must receive if they are to supply a specific quantity of apples. This price is determined by the "opportunity cost" (the highest valued alternative usel of the resources used

This example is simplified for illustrative purposes. It ignores the issues of externalities and imperfect competition. For a more complete discussion, see Hirshleifer (1980). 


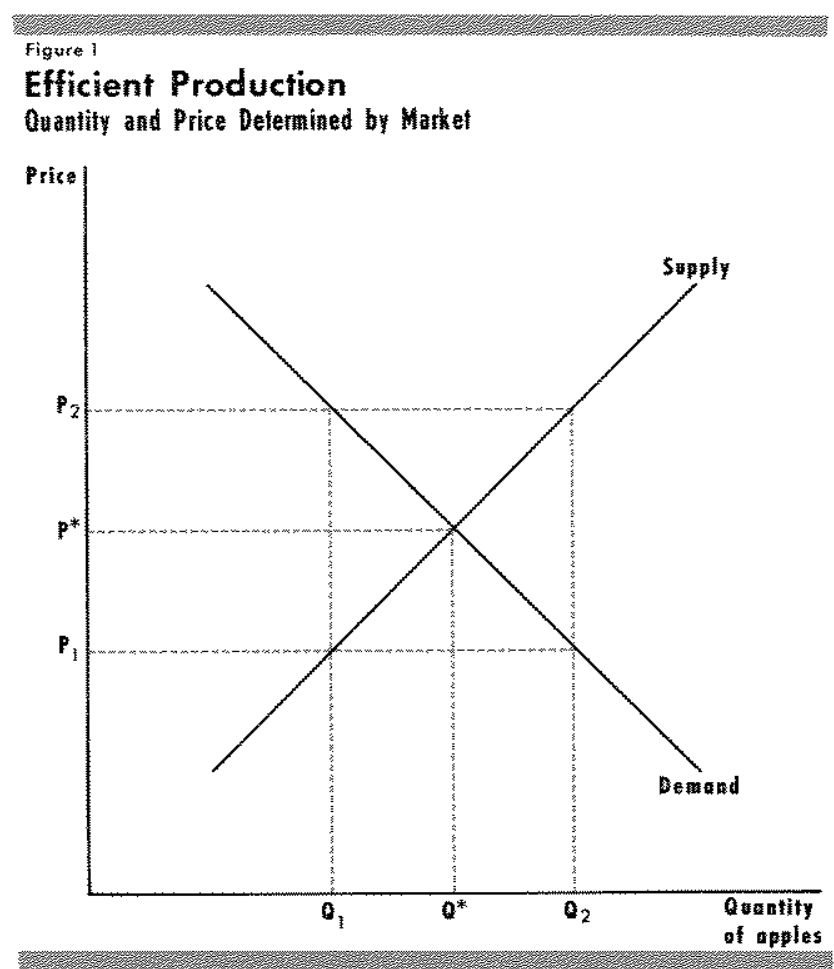

to produce apples. The demand curve in figure 1 portrays the highest price consumers are willing to pay for any specific quantity of apples.

The only price that is common to both the supply and demand curves $\left\{\mathbf{p}^{*}\right\}$ is called the "equilibrium" price; it is the only price at which the quantity demanded equals the quantity supplied $\left(\mathrm{O}^{*}\right)$. This suggests that, at equilibrium, the value that people place on each apple equals the opportunity cost of the resources used to produce it. This is why the competitive market equilibrium represents an economically efficient allocation of resources.

Producing more $\left\{\mathrm{Q}_{2}\right\}$ or less $\left(\mathrm{Q}_{1}\right)$ apples than $\mathrm{Q}^{*}$ would be inefficient. Either too many or too few resources would be allocated to apple production given the value people place on apples compared with other products that those resources could produce. The market will induce producers to provide exactly $\mathrm{Q}^{*}$. If $\mathrm{Q}$, apples were produced, consumers would be willing to pay only $P$, per apple, which is less than the cost of production, $P_{z}$; producers then would decrease output, lowering costs and releasing resources to other higher-valued uses. If $\mathrm{O}_{3}$ were produced, the adjustment would proceed conversely, with output fising and resources for apple production being bid

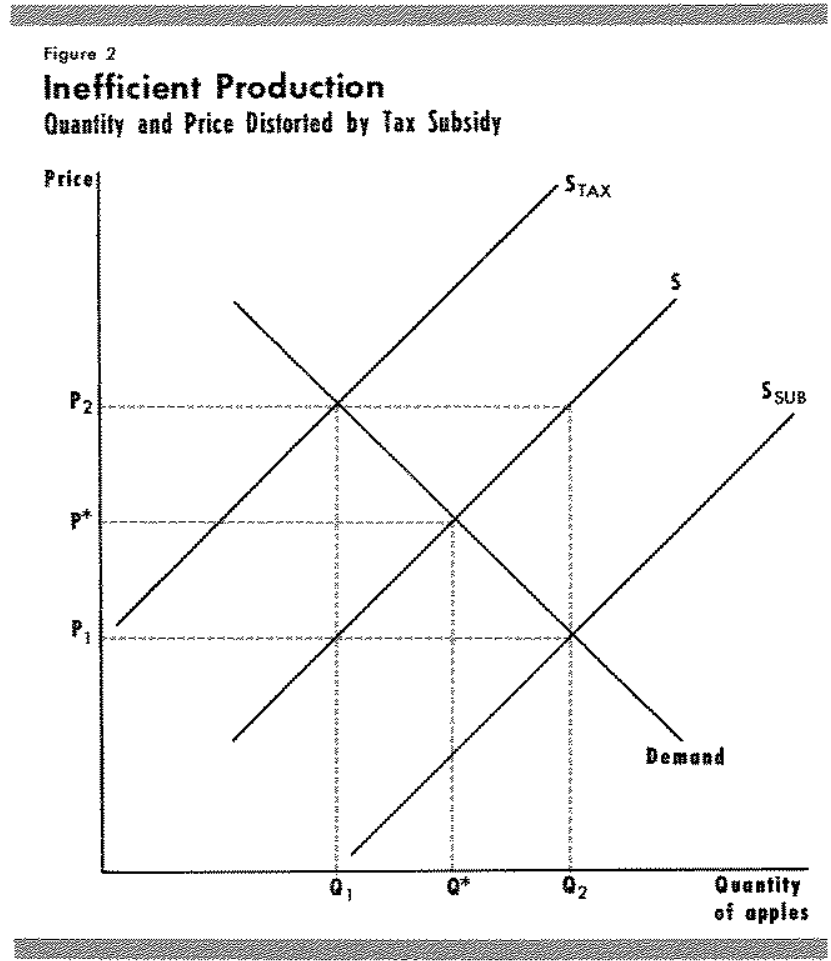

away from other activities whose products were not a highly valued as apples.

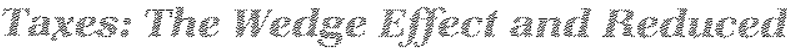

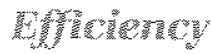

Taxes and subsidies change the allocation of re sources if they alter the incentives confronting producers or consumers. In particular, some taxes of subsidies drive a wedge between the prices that consumers pay and producers receive. A tax on apple production - or on the resources used to product apples - raises firms' costs of production. This situa. tion is depicted in figure 2 as the upward shift in the supply curve to $S_{i x}$ from its position without taxes or subsidies, $S$. As a result of the tax, the equilibrium price of apples rises to $P_{2}$ and the quantity produced (and sold) falls to $\mathrm{O}_{2}$; the economically efficient quan. tity of apples, $\mathrm{Q}^{*}$, is no longer produced because the tax alters producer incentives. At $Q_{1}$, the value that people place on apples $\left\{P_{2}\right.$, exceeds the actual value of the resources used in apple production $\left(\mathrm{P}_{1}\right)$. The wedge, the difference between these values $\left(p_{z}-p_{1}\right)$, is the amount of the tax.

Likewise, subsidizing the production of apples (perhaps through use of tax preferences such as special deductions, credits or abatements) shifts the supply 
curve to $\mathrm{S}_{\text {sex }}$ in figure 2 , resulting in more apples being produced $\left(\mathrm{Q}_{2}\right.$ ) than is economically efficient. At $\mathrm{Q}_{2}$, the value of resources used to produce apples $\left(P_{2}\right)$ exceeds the value that people place on apples $\left(P_{1}\right)$. The difference $\left(P_{z}-P_{1}\right)$ is the amount of the subsidy and a measure of the economic inefficiency.

To summarize, taxes and subsidies cause economic inefficiency by affecting the quantity of the good produced. A tax on production results in too few resources employed in apple production, while subsidies motivate too many tesounces devoted to apple production. ${ }^{3}$ In either case, resources are wasted, the value of the economy's output is reduced and consumers are correspondingly worse off than if there had been no tax or no subsidy.

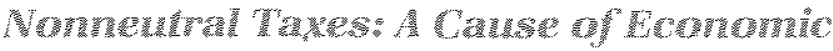

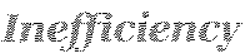

As we have seen, some taxes and subsidies distort resource use, causing inefficiency and making people worse off. Thus, a useful benchmark against which to evaluate both the existing tax system and the potential benefits of tax reform is an ideal, nondistorting "neu" tral" tax system. A neutral tax is one that causes no change in production, consumption or investment. In the context of figure 1 , the imposition of a neutral tax would not alter the position of the supply curve. Consequently, a neutral tax does not induce inefficient resource use.

\footnotetext{
${ }^{3}$ Of course, many people feel that government should guide resource use in order to attain ends not necessarly reflected in market prices. For example, Sen. Russell Long, former chaiman of the Serate Finance Commitee, was characterized in a recent Wall Street Joumal interview as being opposed to "If]elinquishing tax law to the raw forces of the free market. ..":

I do not regard this matter of collecting laxes as simply a matter of bringing in revenue to finance government, he says, "just as the approptiations process seeks to do mote than pay for national defense." To shy away from using the tax code to promote the general weltare, he says, is to be as callous as those who "don't want to be bothered doing anything that benefits anyone except their own greedy selves." (Birmbaum, 1985 )
}

This view is widespread in both houses of Congress and on both sides of the aisle. For example, Senate Finance Committee Chairman Robert Packwood concurs in using the tax code for "legitimate social purposes." (McGinley, 1985). Frequently, such social pur poses are identified with a particular industry as in Sen. Malcolm Waltop's defense of tax preferences for the oll industry: ". . These provisions are backed by sound tax policy and protect a higher public need, namely energy independence." (Wallop, 1985) Conversely, Sen. Bitl Bradley, a proponent of tax reform, argues,

The best altocator of capital is the free market, not the Senate Finance Committee . . as laudabie as all these credits and deductions may be, when you put then in the tax code, rates are higher than they would otherwise be. (McGintey, 1985)
Obviously, any tax that can be reduced by a change of activities is not neutral. For example, an income tax is not a neutral tax because it varies with income. Thus, for individuals, an income tax lowers the cost of leisure (which is not taxed) and induces people to substitute more leisure in place of income-generating (taxed) activities. The extent of this substitution is small, of course, when considering the impact of taxes on corporate income. A copporation's shareholders are unlikely to place much value on the leisure time of corporate assets - or that of the corporation's workers. Consequently, the tax free status of leisure does not preclude neutral taxation of business income.

Although business income taxation could be set up in a nearly neutral fashion, in reality, it seldom is. Tax preferences exist explicitly to encourage specific activities that would not be undertaken otherwise. Capitalintensive industries benefit from certain investment tax credits and accelerated depreciation that are not as remunerative to less capital-intensive industries. Some capital expenditures are treated as a current expense (for example, intangible drilling costs), and depreciation deductions based on historical costs are subject to distortions from inflation. ${ }^{+}$Some business income is not taxed at all (for example, additions to bank reserves for loan defaults and the income of limited liability partnerships), while other business income is taxed twice (corporate dividends). Finally, tax rates vary according to arbitrary realization procedures (capital gains vs. income). In each of these instances, taxes can be altered by changing the firm's production activity - its input mix, legal structure, product mix or timing of sales. To the extent that such tax-induced changes exist, the tax system is not neuiral; the result is a distortion of resource use and economic inefficiency.

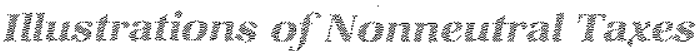

To illustrate the potential allocative effects of the curent business tax structure, consider table 1 , which contains effective tax rates for a sample of large corporations in various industries over the past four years. This table presents average (not marginal) and actual (not expected) lax rates. It nonetheless provides an indication of just how diverse tax rates have been across industries as well as how important tax preferences may have been in allocating resources among

${ }^{4}$ For a discussion of the distortions in depreciation accounting and the tax acts of 198 and 1982 , see Oth (1984) 
Table 1

Comparison of Tax Rates on Large Corporations in Various U.S. Industries, $1980-83$

\begin{tabular}{|c|c|c|c|c|c|}
\hline Industy & 1980 & 1901 & 1982 & 1968 & $\begin{array}{l}1980-83 \\
\text { average }\end{array}$ \\
\hline Aerospace & $164 \%$ & $68 \%$ & $10.6 \% \%$ & $14.0 \%$ & $97 \%$ \\
\hline Beverages? & 280. & 28.0 & 20.5 & 187. & 232 \\
\hline Groadcasting? & ?. & ?.?. & (189. & 18.5 & (3) \\
\hline Chemicals. & 137 & 50 & $(177)$ & $(1,0)$ & 3.6 \\
\hline Conputers and oftice equipment & 249 & 25.3 & 264 & 26.3 & 25.8 \\
\hline Construction ? ? ? ? & (3. & (1) & 15.9 & 07 & $\sqrt{2}+3$ \\
\hline Eectronies and applarices. & 245 & 171 & 14.3 & 74 & 162 \\
\hline Inancial insulutons? & 2.6 & 27 & $(36)$ & 64 & 38 \\
\hline Food processors & 35.6 & 26.8 & 916 & 259 & 295 \\
\hline 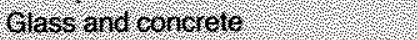 & ?.8. & 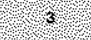 & $\sqrt{3} 2$ & 175 & 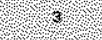 \\
\hline nstrument conolnes & $37 /$ & 266 & 219 & 828 & 295 \\
\hline (nstranos? & ?. 3. & $\sqrt{1.82}$ & 163 & 99 & (7) \\
\hline husstineri companies & ? & (2) & 2,3 & 90 & 8 \\
\hline Mela manufeduring & 163 & 102 & (2) & (1) & 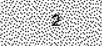 \\
\hline Metal products & $\sqrt{3}+2$ & ?:? & 30.2 & $1 5 \longdiv { 1 }$ & 1. \\
\hline Mining ? ? ? & 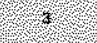 & 4 & ? 3 & 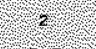 & (3) \\
\hline Motor velicles. & (1) & (?) s & (2). & 135 & (4) \\
\hline Paper and wood products & $(1,4)$ & $(142)$ & 361 & $(0,5)$ & $(29)$ \\
\hline Petroleum & 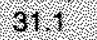 & 21,7 & 18.2 & 213 & 285 \\
\hline Phamaceuticals. & 392 & 039 & 327 & 272 & 329 \\
\hline Aetaling: & 341 & 223 & 204 & 200 & 229 \\
\hline Fubber & 4.8 & (1) 9 & 390 & 196 & (?) \\
\hline Soaps ard cosmetics & 3. & 2) 3 & 30.3 & 356 & 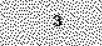 \\
\hline Teleconimunications & ?०? & ?.? & 16 & 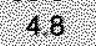 & (3) \\
\hline jobacco & 314 & 313 & 36.6 & 33.8 & 33. \\
\hline Transportation: & & & 8 (2) & (1) 2 & ? \\
\hline Aimes & $\begin{array}{l}3.0 \\
107\end{array}$ & 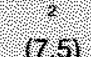 & ?. & 0.3 & 124 \\
\hline $\begin{array}{l}\text { Rajloads? } \\
\text { trucking. }\end{array}$ & 375 & 46.1 & 360 & 34.5 & 382 \\
\hline urintes? & 10.9 & 10.3 & 156 & 7.7 & 107 \\
\hline Wholesalers & ?४:? & ?. & 36.1 & 34.8 & Yे? \\
\hline
\end{tabular}

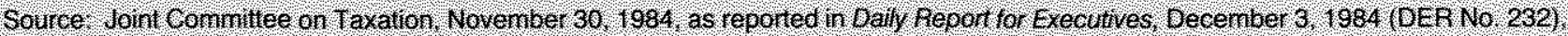
D. 1.1.

Ar ndustry is inctuded in his table only il substantilly the same companes are included hit the sample each year

Rate hol computed on book loss

The 1880 and 1981 rates are not avallable: the 198083 average is nol computed.

4 Sone companies theluded hn the 1982 and 1983 group were classifed with crude ol production in 1980 and 1981 .

In 1980 and 1981 , the utilites group helided ATQT and GT F. The 1980 and 1981 uilities rate is restated to include only electric and gas Utitities.

industries. For example, in 1983 , these rates ranged from an effective tax rate of -1.0 percent that is, a subsidy) for the chemical industry to a 35.6 percent rate for the soaps and cosmetics industry. Furthermore, providers of services faced substantially diverse rates: from financial institutions $(6.4$ percent $)$ to wholesalers (34.8 percent).

In large part, these variations are due to variations ir the tax credits avaliable to the corporations. This i: made clear by an examination of table 2 , which dis plays the data for 1981, the most recent year available 


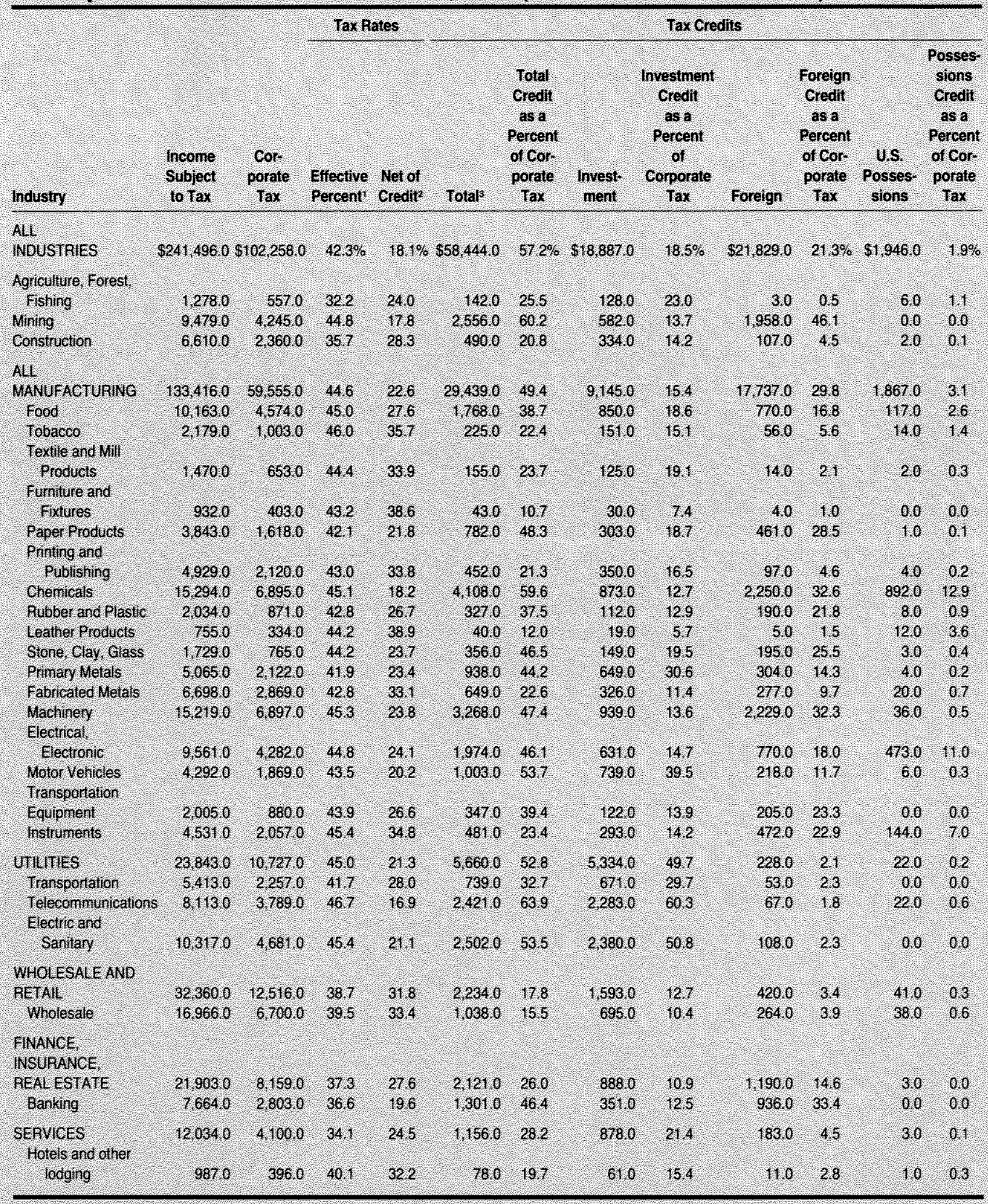

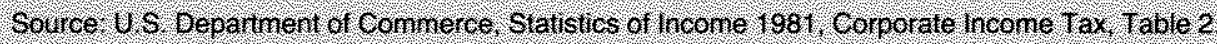

Comporale tax divided by incone subject to lax.

Corporate tax less total credis divided by nicone subjeat to lax.

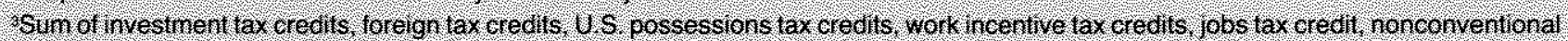
ruels tax credi and rese arch adivilies tax credil 
In general, industries with proportionally high tax credits (table 2) correspond with the large corporations facing low tax rates (table 1 ) and vice versa. In particular, chemicals, banking and utilities each have high ratios of credits to tax and low tax rates for 1981 . Conversely, food, instruments and wholesalers have low ratios of tax credits and high tax rates.

These tax credit ratios differ within industrial groups as well as across them. Within the utilities group, for example, compare tax credit ratios for transportation (32.7) and telecommunications (63.9) in table 2 with their corresponding tax rates in table 1 , or compare the overall finance, insurance and real estate tax credit ratio $(26.0)$ and that for banking $(46.4)$ in table 2 with their corresponding tax rates in table 1.

Profit-seeking investors typically will ensure that their expected after-tax rates of retum are the same across altemative investments, adjusting for risk differences. If tax rates differ across industries, however, the expected before-tax rates of return will vary with the tax rate. Consequently, some higher-earning investment opportunities, when compared on a beforetax basis, will be passed over in favor of investments that have lower before-tax, but higher expected aftertax, rates of return. A neutral tax system would result in the same relative ranking of investment opportunities before and after taxes. Tables 1 and 2 suggest that the present tax structure does not have this characteristic. A tax reform that produced more uniform tax rates across industries would generate more efficient allocation of resources because investments would be chosen more in line with their socially relevant, before-tax yields.

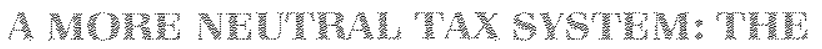

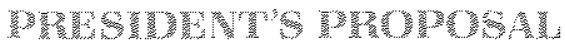

The President's proposed business tax reform consists of four primary adjustments. These adjustments would

(1) Lower the corporate tax rate from 46 percent to 33 percent;

(2) Shift the income tax burden proportionally - from personal taxes (down 6 percent) to corporate taxes lup 24 percenu:

(3) Reduce nonneutalities in the tax code by broadening the tax base and repealing tax subsidies; and

(4) Reduce inflation distortions of resource allocation by indexing inventory costs and depreciation deductions to reflect price changes.
While the focus of our discussion is on the third general feature, the reduction of nonneutralities, the analysis cannot be undertaken without considering the other three.

The President's tax proposal was set up to be "revenue-neutral." Consequently, in order to lower the corporate tax rate yet shift the tax burden from the personal to the corporate tax, it was necessary to increase corporate tax revenues by broadening the tax base - that is, by removing subsidies, exemptions and credits. Their removal provides just about enough additional revenues to offset the impact of the rate reductions, corporate and individual. This revenue enhancement also extends to the reduction of inflation distortions. By indexing depreciation for inflation, much of the rationale for the accelerated depreciation system is removed. Thus, the protection of the depreciation deduction's real value compensates for the lower depreciation deductions.

The impact of these changes on total tax revenues can be seen at the bottom of table 3. Corporate tax and other federal tax revenues over the five years 1986-90 would rise by about $\$ 120$ billion, while personal tax revenues would fall by $\$ 132$ billion. The result is that overall tax revenues over the five years would be approximately unchanged - less than a one-half percent overall decrease - from what they would have been in the absence of tax reform.

Yet, there is more to the reform proposal. The Treasury's estimates of tax revenues over the 1986-90 period are based on an extrapolation of current macroeconomic output and growth; this ignores the reallocative or microeconomic effects of the reforms. With the repeal of various tax subsidies reducing profitability in some business sectors, and the net reduction in marginal tax rates increasing profitability in other sectors, there would be a reallocation of resources. A major argument in favor of this tax reform is that it results in a more efficient allocation of productive resources. That is, the decrease in output in sectors losing tax subsidies will be exceeded by the increase in output in sectors benefiting from net declines in marginal tax rates.

\footnotetext{
This is clearly stated in the summary of The President's Tax Proposals to the Congress for Famess, Growth and Simplicity (p. 7):

Taken together, the President's proposats are "revenue neutrar" (plusorminus $1.5 \%$ of total revenues) - using conventional estimating procedures, without changing macro-economic assumptions. That is, under these assumplions, the proposals woud, when fully effective, raise virtually the same amount of revenue as current law.
} 
Table 3

\section{Major Proposed Corporate Business Tax Reforms (dollar amounts in billions)}

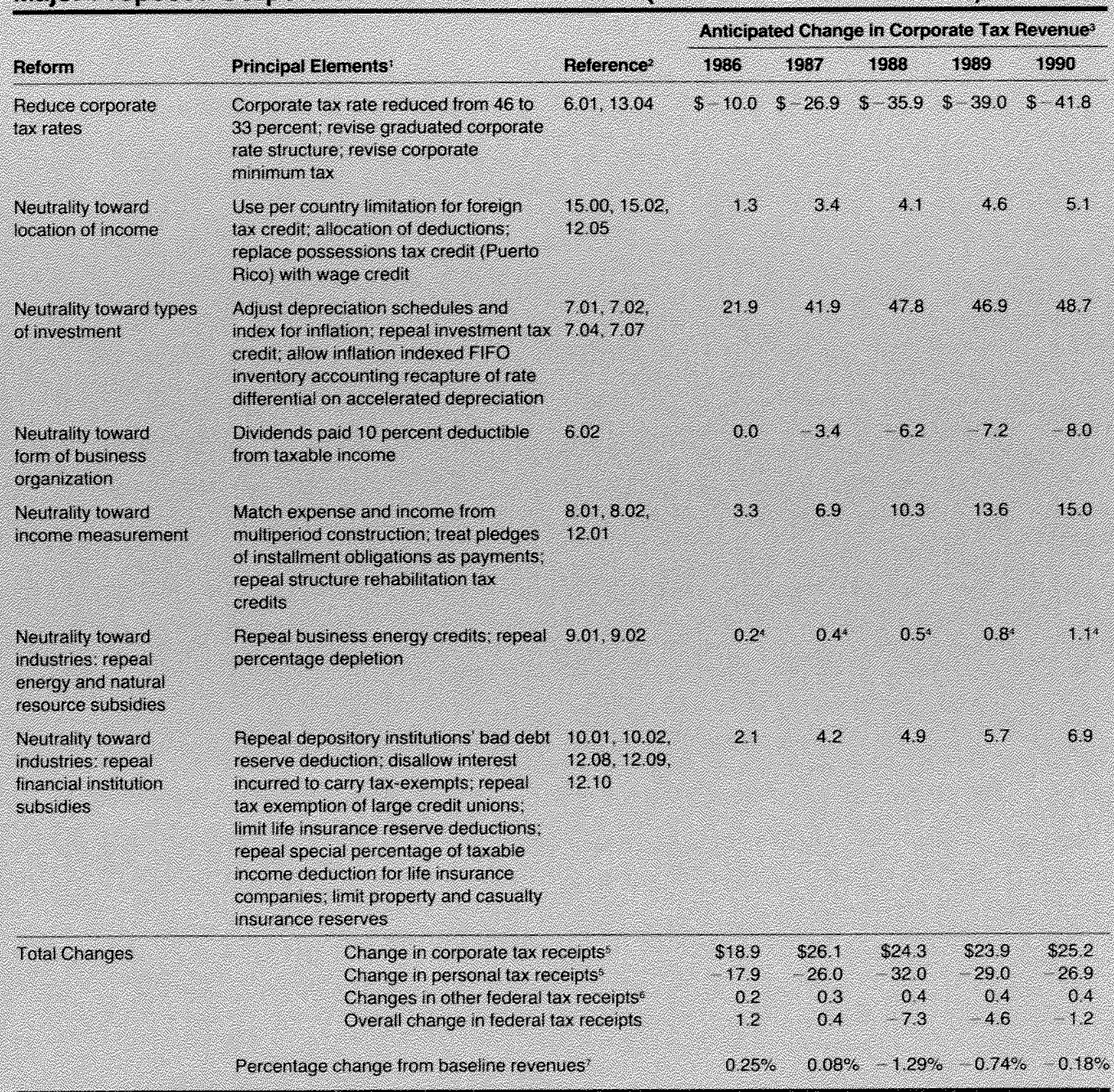

source $P$ fre

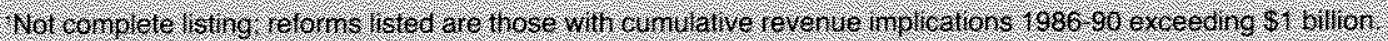

hetereries are 10 subchapter in $P T$ P

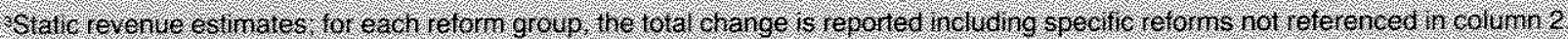

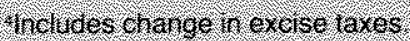

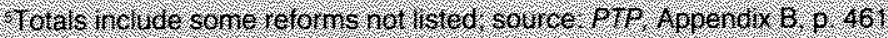

Estare olf and excise taxes:

As estinater by Treasury une curtent taw 
An estimate of the overall gain la part of which results from increased efficiency) due to the Presidenf's proposed reforms has been computed by the Treasury Department:

For reasons suggested above, it is reasonable to expect improved economic performance as a result of the President's tax proposals. The Treasury Department estimates that the effect of the proposals would be to catse real GNP to be at least 1.5 percent higher by 1995 than it would be under current law. Because of the inherent uncertainty in such foreeasts, however, this additional growth has not been added to Administration forecasts and is not reflected in higher revenue estimates. ${ }^{5}$

The estimated 1.5 percent rise in the level of output results from resource reallocations that would be induced by the proposed tax reforms. In that sense, the proposed repeal of many so-called tax expenditures - that is, tax subsidies, exemptions, credits and the like - are sources of a rise in U.S. wealth. Repeal of these tax expenditures, which are subsidies of production in the beneficiary industries, releases resources to higher-valued uses. Thus, the value of production, in other words, income, and its capitalized value, wealth, will rise as a result of the reforms. To see mofe tangibly the source of such tax reform benefits, consider the following description of specific tax reforms outlined in table 3 .

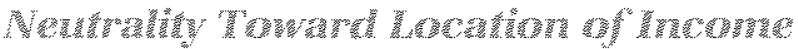

U.S, corporate income is subject to the U.S. income tax regardless of where such income is generated. Corporations, however, receive credits against their U.S. tax liabilities for laxes paid to foreign governments. (See table 2 for the impact of foreign tax credits across industries.) Under current tax law, corporations may receive larger credits from overseas produc

'See The President's Tax Proposals to the Congress for Faimess, Growth and Simplicity, p. 7. Estimates of the gain based on the predecessor to the President's proposal, the U.S. Treasury's Tax Reform For Faimess, Simplicity and Economic Growth (1984), projected similar gains. Allison, Fullerton and Makin (1985) estimated that the Treasury's tax reform proposal would increase GNP by about 1.2 percent over what it would be under 1973 tax law. This corresponds to a rise in wealth of over $\$ 895,1$ billion dollars at current prices. For the current U.S. population, this would amount to over $\$ 3,700$ per person at current prices. See Altison, Fullerton, and Makin (1985), p. 12, table 3. Note that these estimated gains do not exhaust the potential efficiency gains from even more dramatic tax reform. Again, using the 1973 tax code as the base, Ballard, Shoven, and Whalley (1985) have estimated the efficiency gains from an atternative lump-sum tax system designed to avoid completely the resource misallocation that plagues the current system to be between $\$ 4.0$ and $\$ 7.3$ trittion in $1 / 1985$ dollars. tion than from the equivalent domestic production. This amounts to a subsidy of foreign production for U.S. corporations in high-tax foreign countries. The Treasury proposal would eliminate this subsidy by changing the foreign tax credit to a bilateral basis. U.S. corporations would be allowed to claim credit for taxes paid in each foreign country up to a limit of the equivalent U.S. tax. Since the U.S. tax rate under the Treasury proposal would be lower than most indus trial nations, it is likely that some overseas production would be repatriated."

In addition, the proposal would change some ac counting rules that allow firms to reduce tax liabilities by transshipping goods or changing title to them in offshore facilities. Also, the so-called possessions tax credit, which applies predominantly to Puerto Rico, would be replaced with a wage credit. The result of this change would be to limit U.S. corporate tax credit to job-creating production in Puerto Rico. As shown in table 3 , such reforms would result in an expected $\$ 18.5$ billion increase in tax revenues during the 1986-90 period. Not shown in the table, but clearly important, would be any U.S. production increases induced by removal of the tax subsidy.

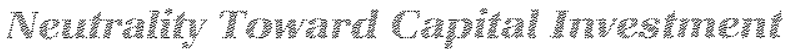

Currently, tax deductions for the cost of depreciation of capital equipment and structures are based on their historical cost. This creates a bias favoring investment in less durable over more durable equipment and structures when the expected inflation rate is moderate or high. The 1981 and 1982 tax acts revised deprectation methods - the Accelerated Cost Recov-

\footnotetext{
This is because the current tax credit is computed on an overall or equivalently, an average basis. For example, suppose a U.S. corpo ration has taxable income of $\$ 1,000$ each in countries $A$ and $B$ country $A$ has a 60 percent tax rate and country $B$ has a 20 percen tax rate. Under current law, the corporation has a U.S. tax liability 0 $\$ 920$ on its foreign income -46 percent of $\$ 2,000$. It teceives a foreign tax credit of $\$ 800-60$ percent of $\$ 1,000$ in country $A$ and $2 C$ percent of $\$ 1,000$ in country $B$ - so that its net U.S. tax on toreigr income is $\$ 120$. Under the feform, the tax credit would be computec with regard to the tax paid in each individual country and limited to the equivalent U.S. tax. Thus, in this example, the foreign tax credi would fall to $\$ 533$ - the maximum of 33 percent under the lowe proposed U.S. corporate tax in country $A$ and the actual 20 percen: in country B. As a result, the profitability of foreign production woutc ctectine relative to domestic production

${ }^{8}$ The corporate tax rates in most major industrial countries exceec the proposed 33 percent U.S. rate: France, 50 percent; Germany 56 percent; The Netheriands, 43 percent; United Kingdom, 35 percent (as of 1986); Japan, 43.3 percent on retained earnings, 33.3 percent on distributed earnings; Canada, 46 percent. See U.S. Treasury (1984), vol. 1, p. 260 .
} 


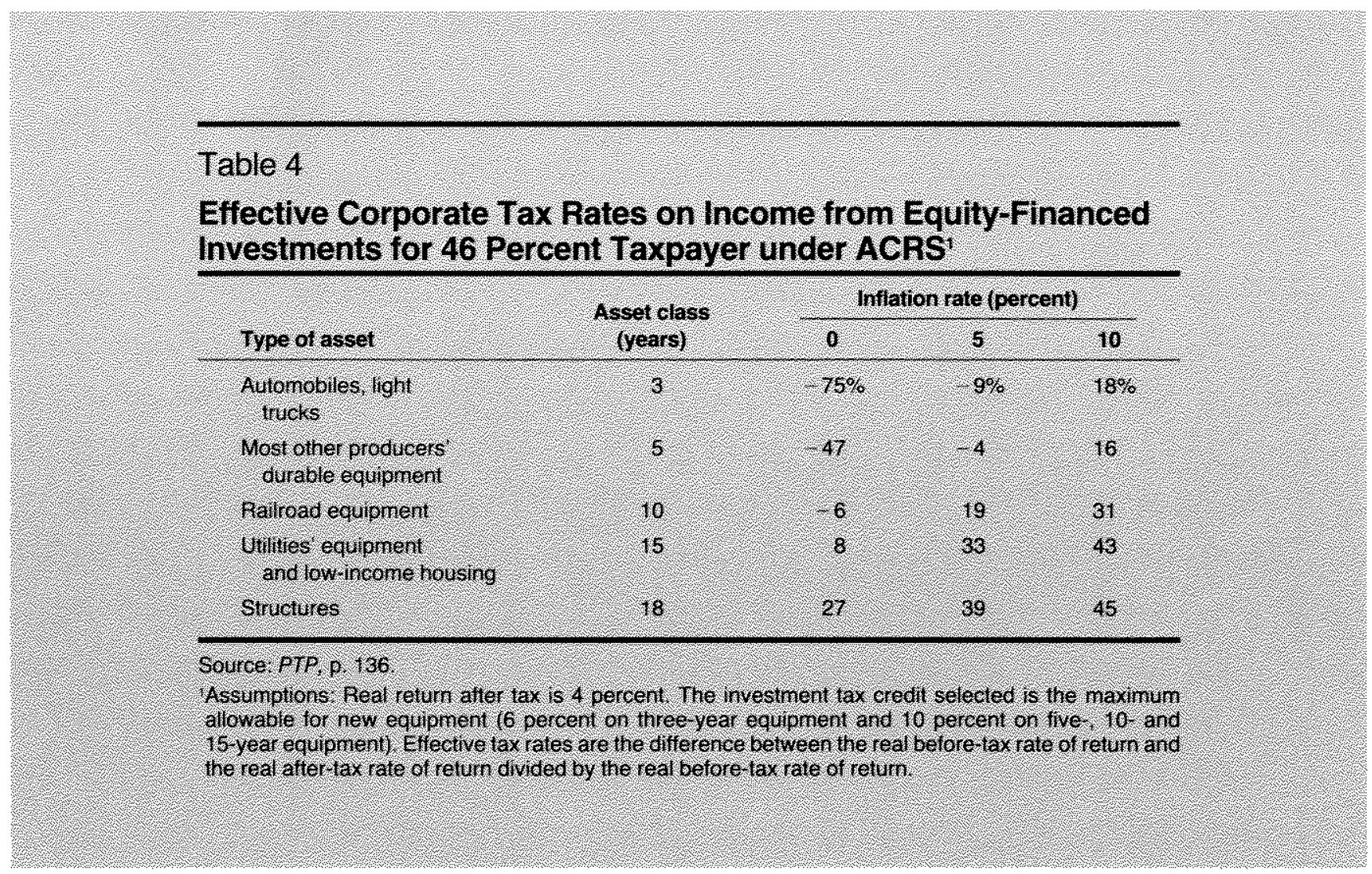

ery System (ACRS) - to counteract the effects of inflation by a more rapid write-off of assets, especially longer-lived assets, such as structures. As table 4 illustrates, however, the bias against more durable equipment and structures remained a feature of the tax code. While the bias narrows as the inflation rate rises, if remains heavily skewed in favor of short-lived equipment investment.

This bias against investment in structures does not impinge evenly on the earnings of all industries. Some industries invest a larger proportion of their capital in equipment than others. As table 5 shows, across all industries, equipment accounts for more than fourfifths of investment, but the proportion varies widely: the tobacco products and pharmaceuticals incustries are on the low side, while the motor vehicle and paper industries are quite high.

The importance of such investment patterns is their impact on tax rates, both from the bias in the depreciation system (table 4) and the investment tax credit (ITC). ITC applies only to equipment; no credit is given for structures. Thus, industries with high proportional investment in equipment table 5 tend to have high ratios of ITC to tax liabilities (table 2) and, consequently, lower tax rates (table 1 ) than firms with lower equipment-tomvestment ratios. For example, the paper products industry, which put 88.2 percent of its investment into equipment, received an ITC covering 18.7 percent of its tax liability and had a net negative tax rate -14.2 percent) in 1981 . In contrast, the tobacco products industry put 68.8 percent of its investment into equipment, resulting in an ITC covering 15.1 percent of its tax liability and a 31.3 percent effective tax rate.

To reduce these biases and their nonneutral tax effects, the President's tax proposal would revamp the depreciation accounting deduction and repeal rrC. ACRS would be replaced with the Capital Cost Recovery system (CCRS). CCRS differs from ACRS in three important respects:

First CCRS would allow cost recovery of the real or inflation-adjusted cost of depreciable assets, rather than only the original, nominal cost. Second, CCRS would assign property among new recovery classes based upon economic depreciation tates. Third, CCRS would prescribe depreciation schedules and recovery periods which produce systematic investment incentives that are neutral across recovery classes. (PTP, p. 138)

Along with this revamping of depreciation accounting, ITC would be repealed. The result is to drastically reduce the biases against durable equipment and structures. As can be seen by comparing tables 4 and 


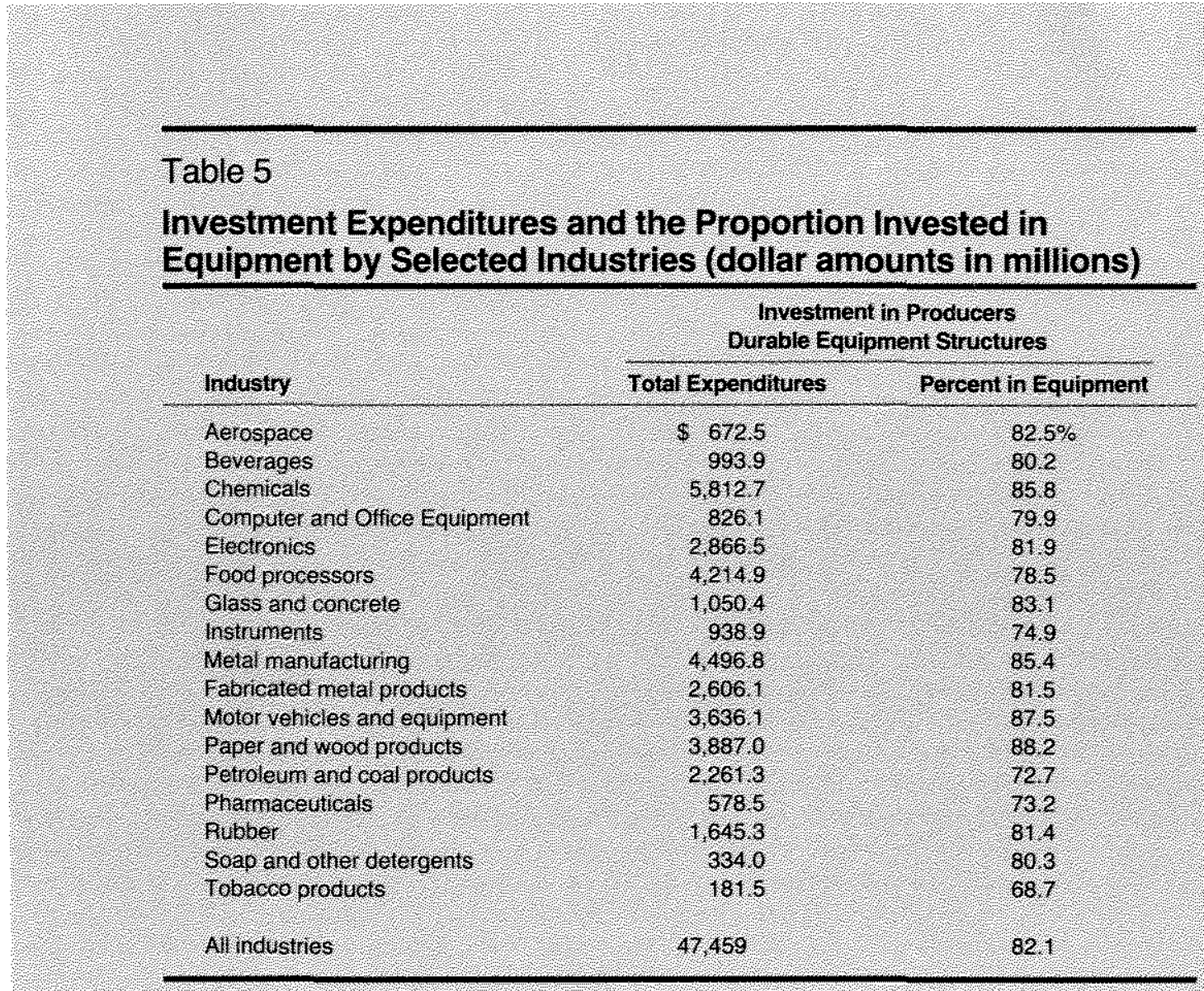

Source US. Deparment of Commerce, Census of Manufacturers, 1977.

6 , the effective tax rates on equipment are changed from subsidies for short-lived equipment to a level tax rate across all durabilities, and the bias against structures is reduced to a few percentage points from its current huge spread. Note also that the indexing for inflation removes that tax distortion as an influence on asset choice. Correspondingly, there would be a narrowing of the tax rate differentials across industries.

It is important to emphasize that these reforms are not intended to be neutral in the sense of removing incentives to invest. The new depreciation scheme (CCRS) retains write-off periods for capital recovery that are shorter than the anticipated economic lives of the assets. Rather, the neutrality sought is between investments of varying durations:

The proposed CCRS depreciation system, in conjunction with repeal of the investment tax credit and other capital and business taxation proposals, makes possible a substantial lowering of statutory lax fates for indviduals and corporations. This reduction in statu- tory tax rates is accomplished without sacrificing in" vestment incentives necessary to stimulate continued economic growth for the economy as a whole. The CCRS depreciation mates and recovery periods produce effective tax rates which would stimulate new investment in depreciable assets. The indexing of depreciation allowarces for inflation and the classificat tion of assets on the basis of economic depreciation would ensure that the CCRS system provides neutral investment incentives. (PTP. p. 148 )

Another form of investment whose yields are distorted by the current tax code is inventories. The costs of maintaining inventories are a relatively more important part of business in the service sector, particularly wholesale and retail trade, than in manufacturing. Inflation reduces the real deductible expense incurred in inventory replacement. This tends to lower the profitability of production in retail and wholesale trade relative to manufacturing both directly and indirectly by inducing a smaller inventory level than otherwise would be held. The President's proposal 


\section{Table 6}

\section{Effective Tax Rates on Equity-Financed Investments in Equipment and Structures}

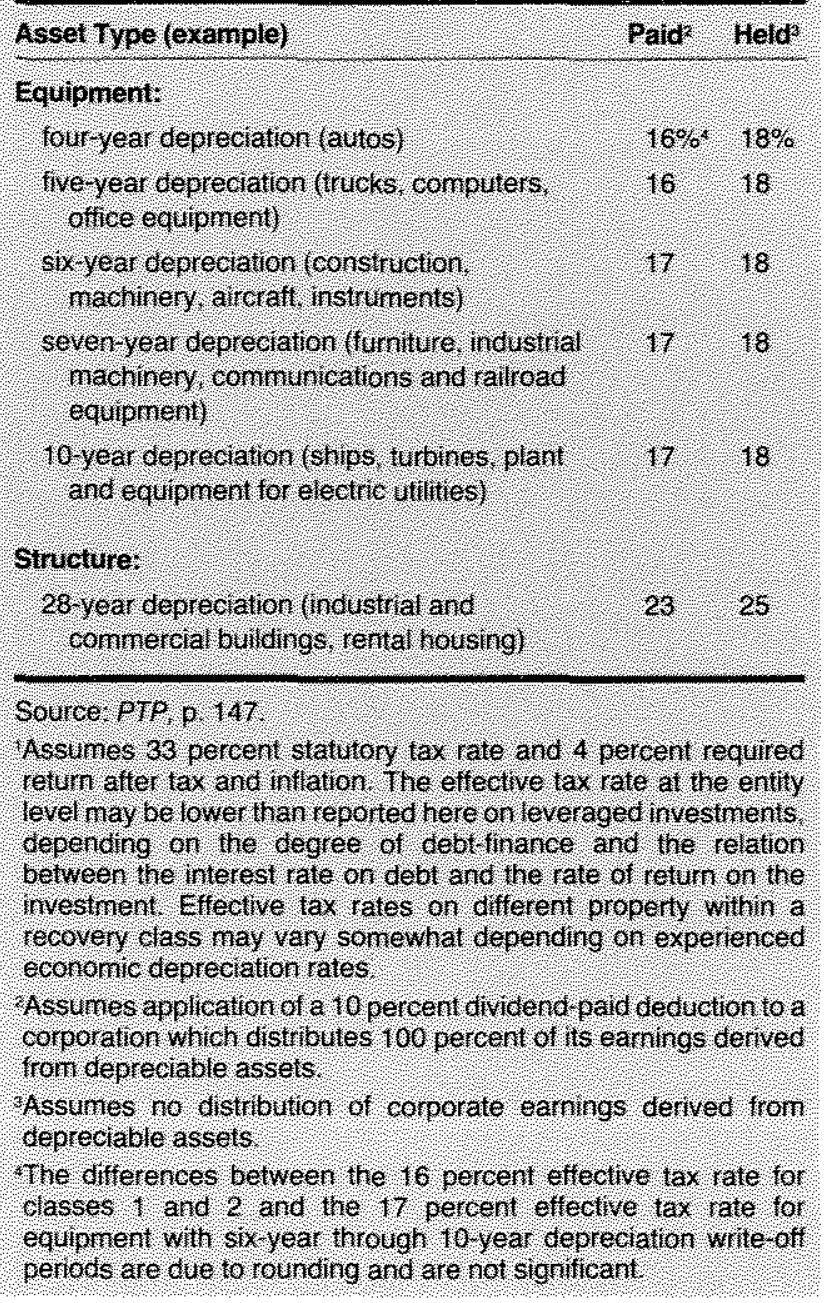

would alleviate this bias by indexing for inflation the inventory replacement expense tax deduction

As shown in table 3 , the result of such changes in the tax code for investment would be an increase in corporate tax revenutes during $1986-90$ of about $\$ 207$ billion.

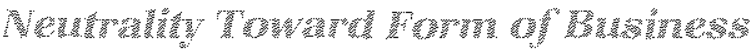

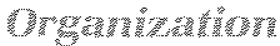

Income generated by corporations is subject to double taxation. It is subject to the corporate tax; then, dividends paid out from this after-tax income to the corporation's shareholders are subject to the personal income tax." In contrast, income from sole proprietorships or partnerships is not taxed at the firm, only as the owner's personal income.

To reduce this distortion, the President's proposal would allow corporations to deduct from taxable income 10 percent of their dividend payout. As shown in fable 3 , this would result in a decline in tax revenues during $1986-90$ of about $\$ 24.8$ billion.

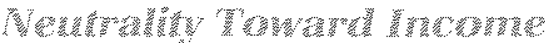

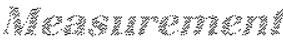

Analogous to the nonneutralittes in the existing depreciation deduction system are distortions in de termining taxable income from the production of assets covering more than one tax year. Examples are the construction of large buthings or ships and the design and production of airctaft. This raises the issue of how to treat the costs of production incurred before the sale. Economic theory suggests these costs should be capitalized and deducted when the project is completed or sold; however, current tax law allows many such costs to be deducted currently, while receipts are not taxed until received, perhaps years later. Revis ing the tax code to require matching of expenses and income from multiperiod production would raise corporate tax receipts by $\$ 39.7$ billion over $1986-90$.

The President's proposed tax reform would repeal structural rehabilitation tax credits, yielding an increase in corporate taxes of about $\$ 1.5$ billion in 1986-90."Also, the interest tax exemption for privatepurpose state and municipal bonds - the somalled industrial development bonds - would be repealed. While this repeal would not increase corporate tax revenues, if would significantly reduce the number of tax-exempt bond issues and increase individual tax revenues - by an estimated $\$ 15.9$ billion over $1986-90$.

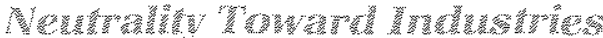

Repeal of Energy and Mining Subsidies - An important tax subsidy to the oil- and gas-producing industry as well as other mining industries is percentage depletion. No longer available to large integrated

\footnotetext{
Tax procedures that avoid double taxation of dividends are common among the principal industrial countries. For example, France has a 50 percent dividend tax credit, Germany effectively excludes 100 percent of dividends paid from double taxalion and Japan excludes 38 percent. See U.S. Treasury (1984), vol. 1, p. 260.

ondividual tax reventes, including those from limited partnerships, which are very common in real estate investment, would rise over $1986-90$ by about $\$ 5$ billion as a result of this repeal. (The President's Tax Proposals to the Congress for Faimess, Growth and Simplicity, p. 459)
} 
petroleum producers, it primarily benefits small independent producers. Percentage depletion allows these small producers to deduct from taxable income a fixed percentage of the value of production to compensate for the reduction in the total amount remaining. "In practice, it results in a total deduction over the life of the well or mine that exceeds the capitalized value of the deposit. The proposed reform would phase out this subsidy of oil and mineral production over the 1986-90 period, except for oil wells with small amounts of production.

Also to be repealed are the business energy tax credits. Originally, these credits were introduced to increase non-petroleum energy production, lower energy use and enhance petroleum production from technically difficult or deep deposits.

In total, the repeal of these energy and mineral industry deposits would yield an increase in colpofate tax revenues over $1986-90$ of about $\$ 3$ billion.

Repeal of Financial Institution Subsidies - As shown in table 1 , the tax rate levied on the U.S. financial and insurance industries has been substantially lower than in other industries. Largely, this has been due to tax subsidies that the reform proposal would eliminate. Primarily, the form of these subsidies has been to permit deductions from taxable income con tributions to reserves for various losses. Under the proposed reforms, only the actual losses would be deductible.

Overall, the Treasury's proposed reforms of financial and insurance institution tax deductions would raise corporate tax revenues during 1986-90 by $\$ 23.8$ billion. In particular, the principal reforms are the following lestimated tax revenue gains during 1986-90 in parentheses):

- the repeal of the deduction for depository institu* tions' contribution to bad debt reserves $(\$ 5.1$ billion);

- the disallowance of the deduction of interest paid by financial institutions to finance purchase of taxexempt securities $(\$ 2.2$ billion); and

\footnotetext{
1The rationale is that production of the mineral essentially entails the removal of a quantity from a fixed inventory of mineral, the original deposit. The producer bought the mineral right, and it is being used up in the production process. Thus, for the same reason that a retail department store deducts the cost of goods sold out of inventory from its gross proceeds to compute taxable income, mineral producers should deduct the proportion of the value of current period production that was capitalized in the mineral lease. The proposal does not dispute the propriety of an appropriately comptted deduction for depletion. It does, however, dispute the fixed percentage form which is arbitrary in relation to the value of the deposit.
}

- a limit on property and casualty insurance company lax-deductible additions to reserves equal to the capitalized value of expected clams 155.6 billion.

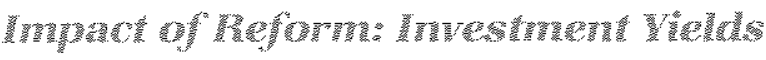

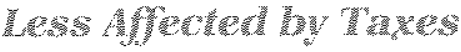

The most important measures of the overall impact of tax reform, in terms of making the tax code more neutral, are the tax rates displayed in table 6 . Comparing these rates with those under current law in table 4, one can see two major differences: no impact on investment due to inflation and nearly level tax rates on investments of diverse durations.

While tax rates are considerably less variable across types of investments under the new tax plan, as levies against corporate income, they are somewhat higher on average. The net result may be a lower aggregate investment rate. A decline in investment, however; would not necessarily imply a lower level of output. The more unifolm tax rates on investments ensure that investment will be induced by market demands - the valuations of consumers - rather than tax subsidies. A resulting decline in investment would mean that some projects undertaken under the old tax code were inefficient. The release of fesources from such inefficient investment would imply an im provement in welfare.

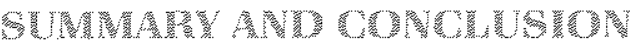

The taxation of business income in the United States has evolved into a complex system of distortions, subsidies and preferences, that has induced corporations to employ valuable resources inefficiently. Output could be increased and people made better off if these tax-generated distortions were eliminated. If it becomes legislation, the President's proposed business tax reform would be a major step in reducing the role that taxation plays in allocating our nation's resources. Those who concentrate on the macroeconomic impacts of the proposal are overlooking some substantial efficiency gains from the proposed changes.

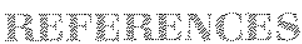

Allson, Michael T., Don Fullerton, and John H. Makin. "Tax Reform: A Study of Some Major Proposals," AEJ Working Paper No. 2 (February 1985).

Ballard, Charles L., John B. Shoven, and John Whalley. "The Total Welfare Cost of the United States Tax System: A General Equilibrium Approach," National Tax Joumal (June 1985), pp. 125-40. 
Birnbaum, Jeffrey H. "Sen. Long. An Architect of the Income-Tax Codes, is Ready to Protect Handiwork From "Reform;", Wall Street Journal, May 7, 1985.

Hirshieifer, Jack. Price Theony and Applications (Prentice-Hall, 1980), pp. $440-45$.

McGinley, Laurie. "The Treasury's Plan To Overhaul Tax Code Sparks Heated Debate," Wall Street Journal, April 3, 1985.

Ott, Mack. "Depreciation, Inflation and Investment Incentives: The Effects of the Tax Acts of 1981 and 1982," this Review (November 1984), pp. $17-30$.

The President's Tax Proposals to the Congress for Fairness, Growth and Simplicity (U.S. Government Printing Office, May 1985).
Rowen, Hobart. "New Tax Rules, New Inequities," Washington Past, June 6, 1985.

Sterngold, James. "Forecasters and the Tax Plan," New York Times, June 8, 1985.

U.S. Department of the Treasury. Tax Reform for Faimess, Simplicity and Economic Growth, (U.S. Treasury Department, November 1984), vols. I and II.

Wallop, Malcolm. "Amplification," letier to Wall Street Joumal, May 7, 1985.

Yemma, John. "Business View of Tax Plan," Christian Science Monitor, June 10, 1985. 